\title{
31. UPPER CRETACEOUS PLANKTONIC FORAMINIFERAL BIOSTRATIGRAPHY FROM THE RIO GRANDE RISE: SITE 516 OF LEG 72, DEEP SEA DRILLING PROJECT ${ }^{1}$
}

\author{
Wolfgang Weiss, Bundesanstalt für Geowissenschaften und Rohstoffe, Hannover, Federal Republic of Germany
}

\begin{abstract}
During Leg 72 in the western South Atlantic, Cretaceous sediments were recovered only at Hole 516F (Rio Grande Rise). Late Cretaceous planktonic foraminifers were found in Cores $516 \mathrm{~F}-89$ through $516 \mathrm{~F}-122$ (between 964 and 1235 $\mathrm{m}$ sub-bottom); they are assigned to the late Coniacian to the latest Maestrichtian. Frequency and preservation of planktonic foraminifers are moderate in the upper Maestrichtian and deteriorate from there to the base. Only the upper Maestrichtian Abathomphalus mayaroensis Zone can be clearly delimited according to the generally accepted planktonic foraminiferal zonation; moreover, some of the more important zonal and stage boundary markers were not found. The Cretaceous/Tertiary boundary is well documented without any major hiatus, and in spite of the poorly recognized zonal boundaries, the Upper Cretaceous sequence is apparently continuous. There are possible correlations between planktonic foraminiferal distribution in Hole 516F and those in Site 356 (São Paulo Plateau) and Sites 357 and 21 (Rio Grande Rise).
\end{abstract}

\section{INTRODUCTION}

Hole $516 \mathrm{~F}$ is situated near the crest of the Rio Grande Rise (western South Atlantic) in $1313 \mathrm{~m}$ of water depth (Fig. 1). At this site, a complete stratigraphic section of Upper Cretaceous through Recent sediments was recovered, terminating in basalt (Unit 8) of the SantonianConiacian at $1251 \mathrm{~m}$ sub-bottom.

Cretaceous foraminifers occur within Lithologic Units 5B (part) and 6. Subunit 5B (between 930 to $1000 \mathrm{~m}$ subbottom) consists of reddish brown nannofossil limestones and contains the Cretaceous/Tertiary boundary in Core 516F-89 ( $964 \mathrm{~m}$ sub-bottom). Unit 6 is characterized by greenish grey and reddish brown limestones interbedded with marly limestones in Subunit 6A (1000$1130 \mathrm{~m}$ sub-bottom) and greenish grey to dark grey recrystallized dolomitic limestones in Subunit 6B (1130$1240 \mathrm{~m}$ sub-bottom). Both the reddish and the greenish intervals are bioturbated. The planktonic foraminiferal distribution at Hole $516 \mathrm{~F}$ is comparable to those established in well-known sections of corresponding age (Sites $21,356,357)$ However, some of the more important Upper Cretaceous planktonic index markers (such as Globotruncana gansseri, G. calcarata, and G. elevata) are not found. Therefore, the zonation based on planktonic foraminifers and the suggested age of the Upper Cretaceous deposits of Hole $516 \mathrm{~F}$ discussed below is tentative except for the late Maestrichtian Abathomphalus mayaroensis Zone.

The specific composition of planktonic foraminifers and other characteristics of the studied samples are listed on the distribution chart in the Appendix (backpocket); the distribution is shown in Figure 2.

Unless otherwise indicated, all core numbers in the text refer to Hole 516F.

\footnotetext{
${ }^{1}$ Barker, P. F., Carlson, R. L., Johnson, D. A., et al., Init. Repts. DSDP, 72: Washington (U.S. Govt. Printing Office).
}

\section{BIOSTRATIGRAPHY}

\section{Coniacian-Santonian}

Interval: Core 122 through Core 114, Section 5

The approximately $55 \mathrm{~m}$ of poorly lithified and recrystallized sediments (Core 125 through Core 119, Section 3) cannot be clearly delimited because of taxonomic difficulties. The lowermost microfaunal assemblage contains some very poorly preserved double-keeled planktonic foraminifers of the Globotruncana renzi-type, which were found in Section 516F-122-1. Within Core 119 , the number of planktonic foraminifers distinctly increases. Globotruncanids (such as G. coronata, G. paraconcavata, $G$. fornicata, $G$. sinuosa, $G$. cf. undulata, $G$. cf. concavata, $G$. cf. pseudolinneiana, and Archaeoglobigerina cf. blowi) and heterohelicids (such as Heterohelix cf. reussi, $H$. globulosa, and Ventilabrella eggeri) occur in relatively low abundances; single-keeled globotruncanids were not found. No exact planktonic foraminiferal zonation or age assignment is given because these are mainly long-ranging planktonic species. The distribution of few specimens of Globotruncana cf. concavata (Core 119, Section 2, through Core 117) allows a possible subdivision of this interval. In Core 117, Section 1, the last occurrence of $G$. cf. concavata coincides with the first appearance of Ventilabrella eggeri; this horizon could be dated as middle to late Santonian.

\section{Campanian}

Interval: Sections 516F-114-4 through 516F-101-4

Well-known zonal markers of planktonic foraminifers are absent within this sequence. The Santonian/Campanian boundary discussed by Wonders (1980) was not clearly recognized at Hole 516F because neither Globotruncana elevata nor any true $G$. asymetrica $(=G$. carinata) could be identified. The boundary was placed, therefore, at the first appearance of G. arca at Core 114, Section 4. According to various references (Pessagno, 


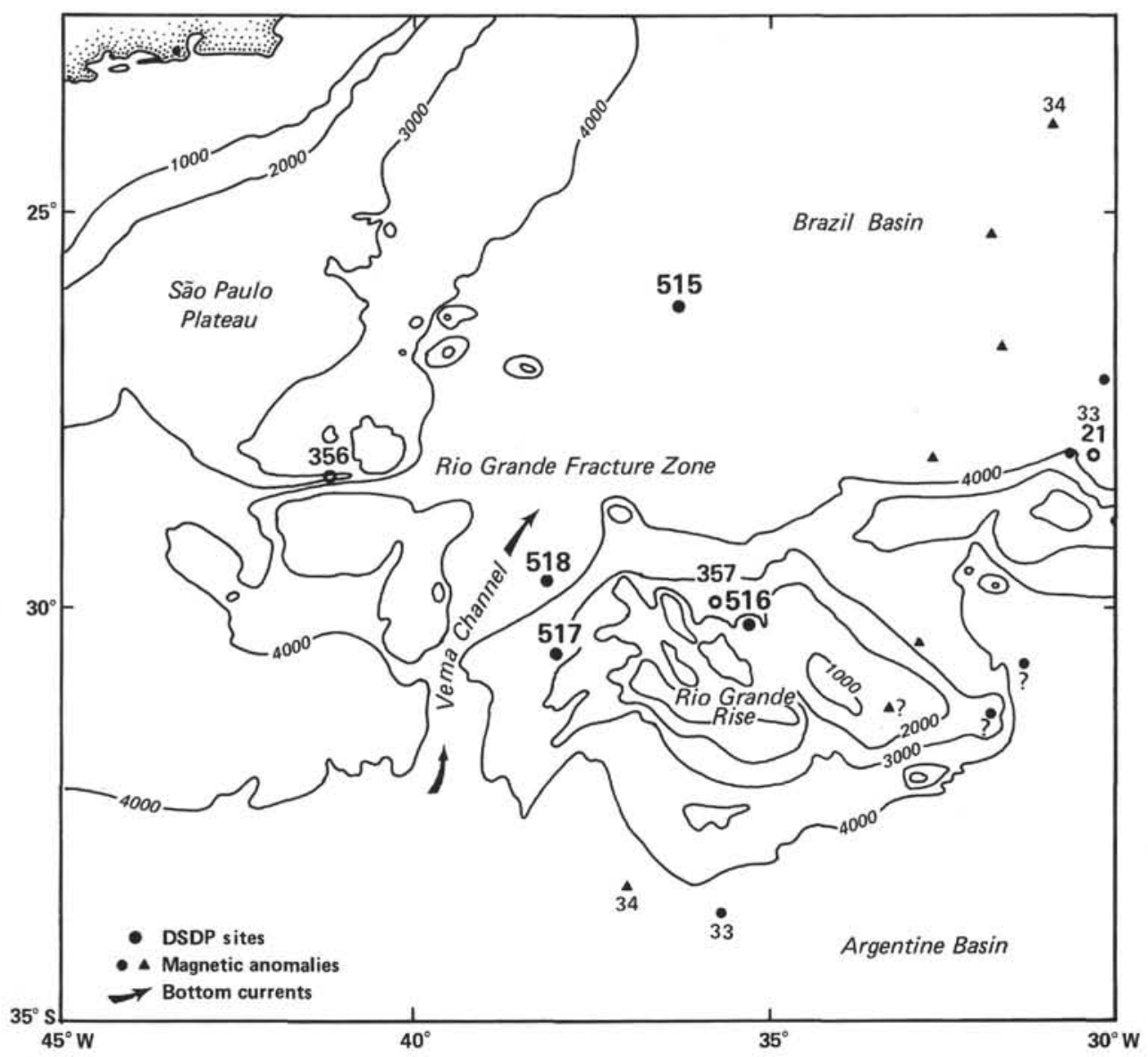

Figure 1. Locations of Sites 516 (Leg 72), 356 and 357 (Leg 39), and 21 (Leg 3).

1967; Petters, 1977), G. arca makes its biostratigraphic entrance in the lower Campanian.

The Campanian sequence is distinguished as follows:

1) Globotruncana arca Zone: Sections 516F-114-4 through $516 \mathrm{~F}-112-3$

Globotruncana renzi, G. coronata, G. paraconcavata, large specimens of $G$. fornicata, G. cf. undulata, $G$. cf. pseudolinneiana, Archaeoglobigerina cf. blowi, G. arca, G. cf. asymetrica, Heterohelix reussi, $H$. globulosa, Pseudotextularia elegans, $H$. pulchra.

$P$. elegans occurs together with $G$. arca at the base of the zone. $G$. cf. asymetrica has a very short range within this zone.

Within and at the end of the $G$. arca Zone, a sudden change in the planktonic foraminiferal assemblage becomes obvious; species belonging to the marginotruncanids (such as G. renzi, G. coronata, G. paraconcavata, $G$. cf. undulata, and $G$. cf. pseudolinneiana) disappear successively; they were followed in the overlying $G$. ventricosa Zone by those species belonging to the globotruncanids s.s. The disappearance of the multiserial heterohelicid Ventilabrella eggeri also characterizes this change, one typical of planktonic foraminiferal assemblages in the lowermost Campanian.

2) Globotruncana ventricosa Zone: Sections 516F$112-2$ through $516 \mathrm{~F}-104-5$
Globotruncana fornicata, Archaeoglobigerina cf. blowi, G. arca, G. rosetta, G. stuartiformis, G. stephensoni, G. ventricosa, G. linneiana, G. bulloides, G. subspinosa, Rugoglobigerina rugosa, G. obliqua; Heterohelix globulosa, Pseudotextularia elegans, $H$. pulchra, $H$. striata, $H$. planata, Pseudoguembelina costulata.

$G$. ventricosa appears together with other species of the elevata, arca, and linneiana groups. They occur in relatively low abundance, especially in the upper parts of this zone. Pseudoguembelina costulata occurs first in Core 109 , Section 1 , with slightly striate or seemingly nonstriate specimens.

3) Unzoned Interval: Sections 516F-104-4 through $516 \mathrm{~F}-101-4$

Globotruncana fornicata, Archaeoglobigerina cf. blowi, G. arca, G. rosetita, G. stuartiformis, G. stephensoni, G. linneianna, G. bulloides, Rugoglobigerina rugosa, G. obliqua, G. cf. mariei (= G. cretacea), G. scutilla, Globotruncanella havanensis; Heterohelix globulosa, Pseudotextularia elegans, $H$. pulchra, $H$. striata, $H$. planata, Pseudoguembelina costulata, $H$. pseudotesseca, Pseudotextularia sp., Planoglobulina carseyae.

The first appearance of Globotruncana scutilla is at the base of the unzoned third interval of this sequence. It is distinguished by the entrance of two characteristic heterohelicids, which are named in open nomenclature 
by scarcity of specimens: Pseudotextularia sp. could be the ancestor of Planoglobulina carseyae, and Heterohelix sp. is thought to grade into Gublerina robusta.

The first appearances of $P$. carseyae and Globotruncana havanensis mark the upper part of this unzoned interval, whereas forms such as G. obliqua, G. bulloides, and Archaeoglobigerina cf. blowi disappear. According to Premoli Silva and Boersma (1977), Globotruncanella havanensis first occurs within the Globotruncana calcarata Zone, indicating that this interval is late Campanian.

The Campanian sequence of Hole $516 \mathrm{~F}$ has a thickness of about $107 \mathrm{~m}$. Using the van Hinte (1976) numerical time scale, the calculated accumulation rate amounts to $1.3 \mathrm{~cm} / 1000 \mathrm{yr}$. This approximate value is two times higher than that for Site 356, and three times higher than for Site 21.

The upper part of the $G$. ventricosa Zone contains a lithologic interval of an unusual red coloration between Sections $516 \mathrm{~F}-108-2$ and $516 \mathrm{~F}-104-1$. The planktonic foraminifers show no direct dissolution effects; nevertheless, their diversity and abundance decrease distinctly, and their preservation is very poor (see Appendix A). Some samples contain no planktonic foraminifers and only residues of badly preserved benthic foraminifers, indicating a strong plankton diminution during this interval. The same observations were made at other sites from various depths throughout the central and South Atlantic (Premoli Silva and Boersma, 1977). An explanation for the red coloration is not clear, but together with the bioturbation, it could be interpreted "as a result of the oxidising stage of open marine sediments originally deposited under reducing conditions (originally green sediments)" (Bonatti, cited in Premoli Silva and Boersma, 1977).

\section{Maestrichtian}

Interval: Section 516F-101-3 through Sample 516F$89-5,29.3 \mathrm{~cm}$

The Campanian/Maestrichtian boundary at Hole $516 \mathrm{~F}$ could not be exactly determined on the basis of planktonic foraminifers. Globotruncana calcarata, the uppermost Campanian guide fossil, is absent, and other lower Maestrichtian zonal markers, such as $G$. tricarinata or Rugotruncana subcircumnodifer, were missing. Generally, the lower Maestrichtian could not be recognized by the absence of $G$. calcarata. Possible signs of a lithologic or biostratigraphic break were not observed in this interval. In addition, the middle Maestrichtian could not be identified by the absence of typical specimens of $G$. gansseri. The first appearance of $G$. falsostuarti in Section 516F-101-3 apparently, therefore, indicates the approximate position of the Campanian/ Maestrichtian transition.

The Maestrichtian interval at Hole $516 \mathrm{~F}$ was subdivided into two zones:

1) Globotruncana falsostuarti Zone: Sections 516F101-3 through 516F-95-3

Globotruncana fornicata, G. arca, G. rosetta, G. stuartiformis, G. stephensoni, G. linneiana, Rugoglobigerina rugosa, G. scutilla, Globotruncanella havanensis, Globotruncana falsostuarti, G. gagnebini, G. aegyp- tiaca, $R$. milamensis, $G$. trinidadensis, $R$. cf. scotti, $R$. hexacamerata; Heterohelix globulosa, Pseudotextularia elegans, $H$. pulchra, $H$. striata, $H$. planata, Pseudoguembelina costulata, $H$. pseudotessera, Pseudotextularia sp., H. sp., Planoglobulina carseyae, Gublerina robusta, G. cuvillieri, P. riograndensis, P. manuelensis, Pseudoguembelina kempensis, Pseudotextularia deformis.

Globotruncana falsostuarti, G. gagnebini, and G. aegyptiaca occur at the base of this zone. The rugoglobigerinids are well developed with Rugoglobigerina milamensis, $R$. cf. scotti, and $R$. hexacamerata. $G$. trinidadensis has a short range during this interval, in contrast to Site $\mathbf{3 5 6}$ where it ranges into the Abathomphalus mayaroensis Zone. The heterohelicids show two multiserial events with the first occurrence of Gublerina robusta and of G. cuvillieri at Core 100 followed by Planoglobulina riograndensis and $P$. manuelensis, which have a limited distribution between Cores 99 and 96 . In the upper part of the Globotruncana falsostuarti Zone, Pseudoguembelina kempensis and Pseudotextularia deformis were observed.

2) Abathomphalus mayaroensis Zone: Section 516F95-2 through Sample 516F-89-5, $29.3 \mathrm{~cm}$

Globotruncana arca, G. rosetta, G. stuartiformis, $G$. linneiana, Rugoglobigerina rugosa, Globotruncanella havanensis, Globotruncana gagnebini, G. aegyptiaca, $R$. cf. scotti, $R$. hexacamerata, Abathomphalus mayaroensis, G: lamellosa, G. stuarti, G. cf. gansseri, G. contusa, G. insignis, G. conica, Globigerinelloides volutus, Globotruncana patelliformis, G. cf. elevata, G. galeoides; Heterohelix globulosa, Pseudotextularia elegans, $H$. pulchra, $H$. striata, $H$. planata, Pseudoguembelina costulata, Pseudotextularia sp., Planoglobulina carseyae, Gublerina robusta, G. cuvillieri, Pseudoguembelina kempensis, Pseudotextularia deformis, Racemiguembelina intermedia, $R$. fructicosa, Pseudoguembelina costata, $H$. semicostata, Planoglobulina brazoensis, $P$. acervulinoides, Pseudoguembelina palpebra, $P$. punctulata, Planoglobulina multicamerata, Pseudoguembelina sp.

The Abathomphalus mayaroensis Zone is the bestrecognized Upper Cretaceous planktonic foraminiferal zone at Hole $516 \mathrm{~F}$. The moderate preservation and the relatively high abundance of late Maestrichtian planktonic foraminifers indicate favorable and stable ecologic conditions. This zone is indicated by the first occurrence of Abathomphalus mayaroensis, accompanied by other globotruncanids, such as Globotruncana lamellosa, G. stuarti, G. cf. gansseri, and G. contusa. G. fornicata, $G$. scutilla, and $G$. falsostuarti disappear at the base of this zone. Whereas G. rosetta, G. gagnebini, G. cf. gansseri, G. insignis, G. conica, and Globigerinelloides volutus are restricted to the lower part of this zone, Globotruncana patelliformis, G. cf. elevata, and G. galeoidis were found in the upper part of the zone. The multiserial heterohelicids are represented with Racemiguembelina fructicosa and Planoglobulina acervulinoides and related forms; $P$. multicamerata is restricted to the upper part of this zone. Pseudoguembelina costata $(=P$. excolata) and $P$. palpebra are common throughout the section; the last species attempts a multiserial-like stage 




Figure 2: Range of planktonic foraminifers at Hole 516F, Coniacian/Santonian to upper Maestrichtian (water depth $=1313 \mathrm{~m})$. 


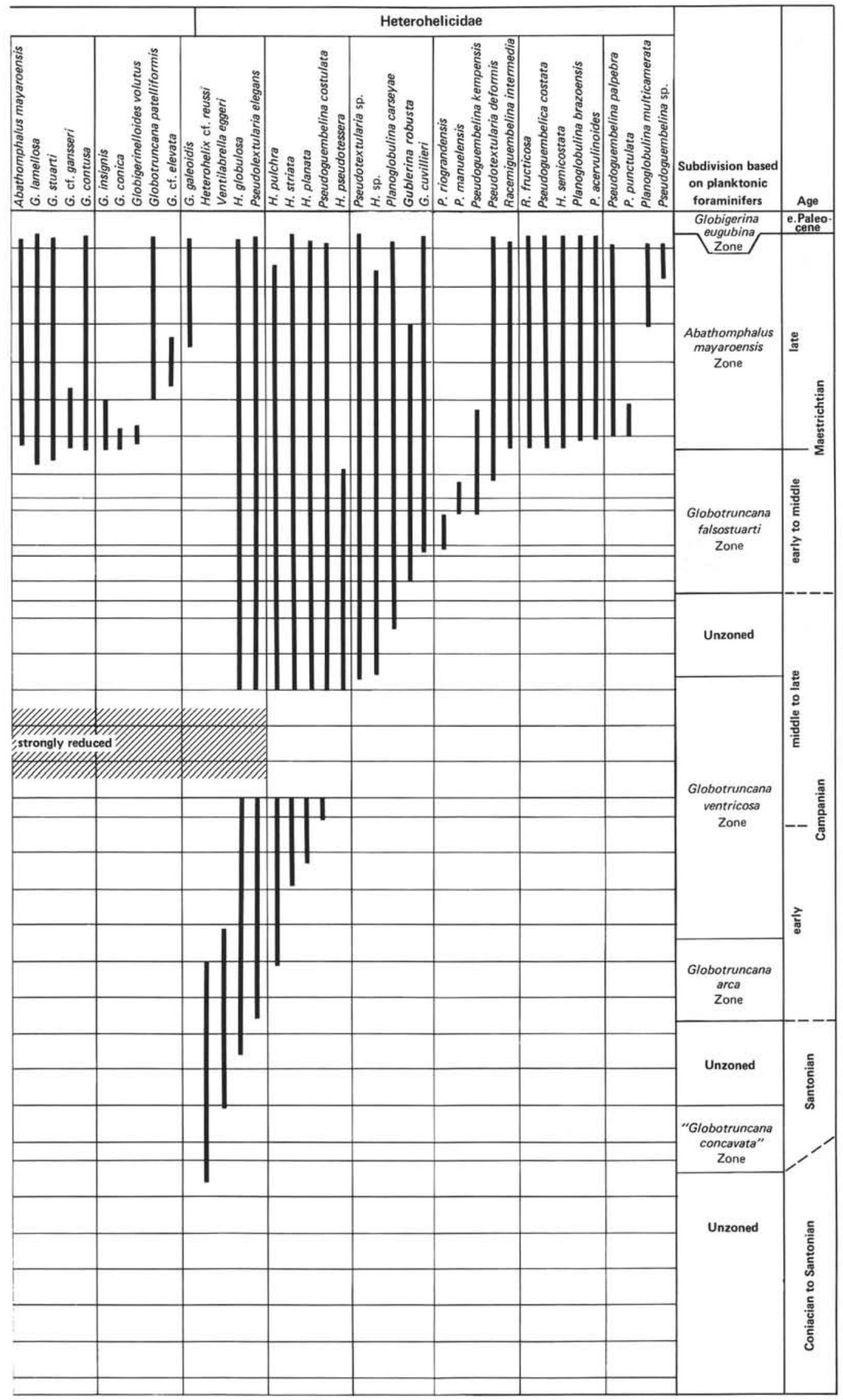


(P. sp.) in the upper part of the Abathomphalus mayaroensis Zone.

The Uppermost Cretaceous at Hole $516 \mathrm{~F}$ is assigned to Sample 516F-89-5, 29.3-31.2 cm, and is characterized by a total extinction of all globotruncanids and heterohelicids. The following earliest Tertiary Globigerina eugubina Zone is present and indicates that no major hiatus exists at the Cretaceous/Tertiary boundary at this site.

Within the Maestrichtian interval, two other layers with conspicuous red coloration are noticed; the first red layer ranges between Sections 516F-96-2 and 516F94-2, (dated as middle to late Maestrichtian, below the Abathomphalus mayaroensis datum line), whereas the second lies within the late Maestrichtian A. mayaroensis Zone between Sections 516F-92-2 and 516F-91-2. In contrast to the first interval of red coloration (Sections $516 \mathrm{~F}$ 108-2 through 516F-104-1), these two intervals show no change in relative abundance and diversity of planktonic foraminifers. Dissolution effects on the planktonic foraminifers are absent within all three red intervals.

\section{CORRELATIONS TO PREVIOUS DSDP SITES IN THE WESTERN SOUTH ATLANTIC}

(Sites 21, 356, 357)

In Figure 3, the Cretaceous of Hole 516F is compared with the Cretaceous sequence drilled in Leg 39, Holes 356 (São Paulo Plateau) and 357 (Rio Grande Rise), and in Leg 3, Hole 21 (Rio Grande Rise).

The spot-cored Mesozoic sequence at Site 356 (São Paulo Plateau) extended from Section 356-29-3 through Core 356-44 with a total thickness of $333 \mathrm{~m}$. Several zones from the Ticinella breggiensis Zone (late Albian) to the Abathomphalus mayaroensis Zone (late Maestrichtian) are recognizable. Hole 356 differs from Hole $516 \mathrm{~F}$, which has no Middle Cretaceous record of sediments. Basaltic basement was reached below SantonianConiacian strata. In contrast to Hole 356, the Coniacian-Santonian sequence of Hole $516 \mathrm{~F}$ cannot be assigned to distinct planktonic foraminiferal zones. The lower and upper Campanian boundaries are also not clear because of the absence of Globotruncana elevata and $G$. calcarata. However, the change within the planktonic foraminifers from the marginotruncanids to the globotruncanids, recognizable in the lower Campanian at Hole $516 \mathrm{~F}$, corresponds to a similar change between Cores 356-35 and 356-34. The early to middle Maestrichtian of Hole $516 \mathrm{~F}$ is not so well defined as that of Hole 356 because of the lack of zonal markers such as Globotruncana tricarinata and $G$. gansseri. The first appearance of Abathomphalus mayaroensis is the best equivalent datum plane at both sites.

The Cretaceous sequence at Site 357, located near Site 516, was also spot-cored from Core 357-31 through Core 357-51 with a total penetration of $209 \mathrm{~m}$. Although Site 357 is characterized by slumping and mixing of sediments throughout many levels, several zones from the Globotruncana concavata Zone (Santonian) through the Abathomphalus mayaroensis Zone (late Maestrichtian) were recognized. The preservation of planktonic foraminifers is also generally poor and reworked, and in situ

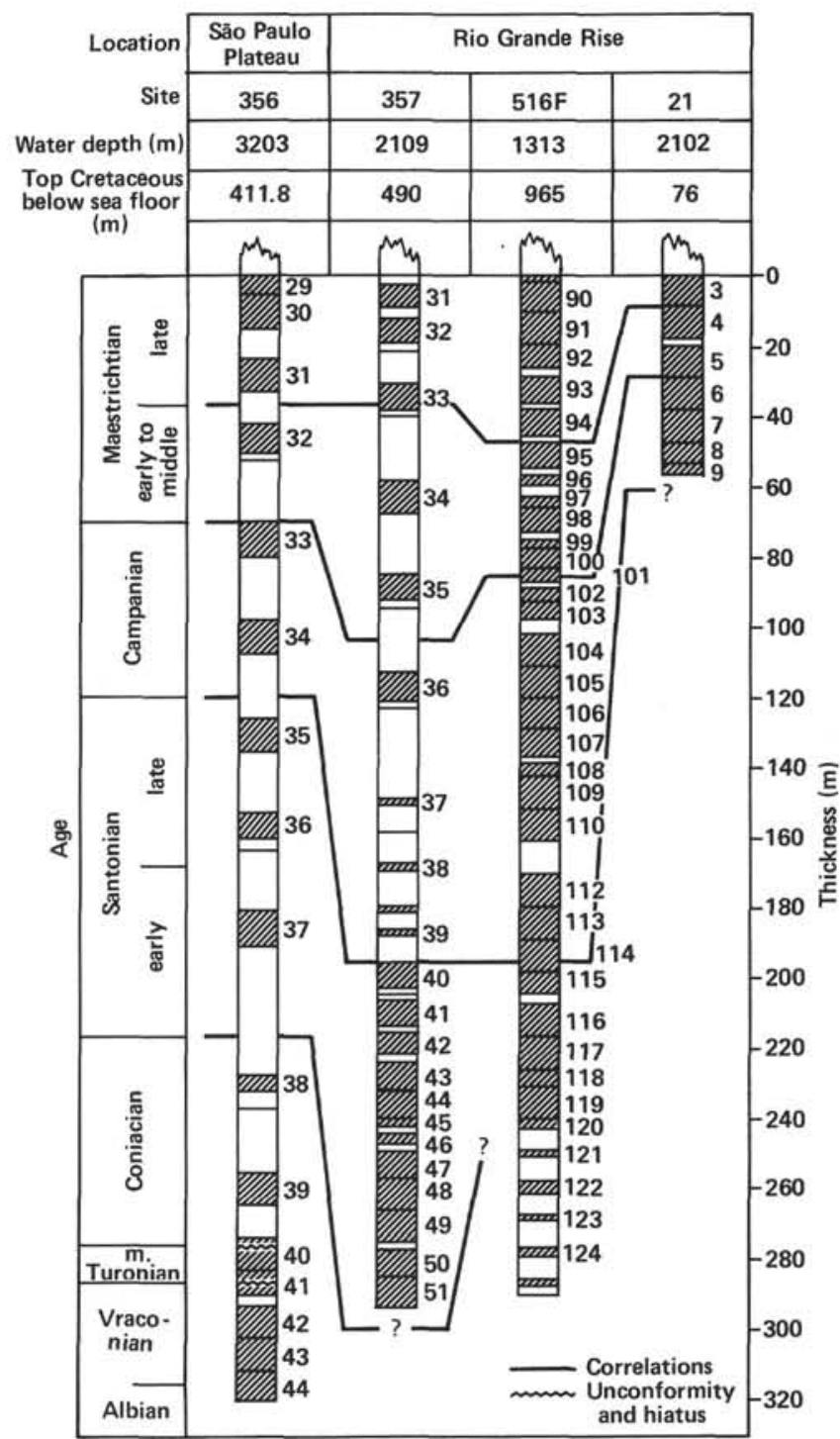

Figure 3. Thickness of Cretaceous sediments versus age at Site 356 (São Paulo Plateau) and at Sites 357, 516, and 21 on the Rio Grande Rise (after Premoli-Silva and Boersma, 1977). Shaded areas show the recovery per each core; core numbers are to the right of shaded columns.

assemblages are not distinguishable. The Campanian interval between Cores 357-39 and 357-36 shows zonal marker species only at its base. Most of the overlying sediments are barren of planktonic foraminifers; this could be correlated with the interval of fewer planktonic foraminifers between Cores $516 \mathrm{~F}-107$ and $516 \mathrm{~F}-105$. The Globotruncana tricarinata Zone and the G. gansseri Zone between Cores 357-36 and Section 357-33-5 could be tentatively attributed to the early to middle Maestrichtian G. falsostuarti Zone between Cores 516F-100 and 516F-95, Section 2. Where Abathomphalus mayaroensis appears at both sites, the diversity and abundance of planktonic foraminifers is also high; correlation is easy and indicates the widespread favorable paleooceanic conditions at the end of the Maestrichtian.

A complete sequence about $65 \mathrm{~m}$ thick was recovered at Site 21, situated northeast of Hole 516F. All plank- 
tonic foraminiferal zones from the Globotruncana ventricosa Zone (lower to middle Campanian) to the $\mathrm{Aba}$ thomphalus mayaroensis Zone (upper Maestrichtian) are documented by well-preserved microfaunas. Although no break or hiatus of the deposition record was observed at Site 21, the G. tricarinata Zone and the $G$. gansseri Zone of lower to middle Maestrichtian were surprisingly not found in my own post-cruise studies. Correlation is possible, however, for the Abathomphalus mayaroensis Zone and the Campanian/Maestrichtian boundary at both sites.

The comparison between Holes 356, 357, 516F, and 21 shows the different beginnings of the stratigraphic history; a generally much greater thickness of Cretaceous sediments and poorer biostratigraphic record, especially in the lower and middle Campanian, characterizes Holes 356,357 , and $516 \mathrm{~F}$. In contrast, the Campanian sequence of Site 21 is complete and well documented. The upper Maestrichtian Abathomphalus mayaroensis Zone is the best-correlated interval at all sites.

\section{CONCLUSIONS}

The examination of the planktonic foraminifers in the Upper Cretaceous sediments recovered at Site 516 (Rio Grande Rise, South Atlantic) allows the precise dating of only one interval, the Abathomphalis mayaroensis Zone; only broad age determinations are possible for the others. In all, five planktonic foraminiferal zones and three unzoned intervals are recognized. From bottom to top these are:

1) Unzoned interval, possibly Santonian to Coniacian; Sections 516F-122-1 to 516F-119-3.

2) "Globotruncana concavata" Zone, possibly Santonian; Section 516F-119-2, to Core 516F-117.

3) Unzoned interval, possibly upper Santonian; Sample $516 \mathrm{~F}-116, \mathrm{CC}$ to Section $516 \mathrm{~F}-114-5$.

4) Globotruncana arca Zone, possibly lower Campanian; Sections $516 \mathrm{~F}-114-4$ to $516 \mathrm{~F}-112-3$.

5) Globotruncana ventricosa Zone, possibly lower to upper Campanian; Sections 516F-112-2 to 516F-104-5.

6) Unzoned interval, possibly upper Campanian; Sections $516 \mathrm{~F}-104-4$ to $516 \mathrm{~F}-101-4$.

7) Globotruncana falsostuarti Zone, possibly lower to middle Maestrichtian; Sections $516 \mathrm{~F}-101-3$ to $516 \mathrm{~F}$ 95-3.

8) Abathomphalus mayaroensis Zone, upper Maestrichtian; Sections 516F-95-2 to 516F-89-5.

This Upper Cretaceous planktonic foraminiferal zonation is very tentative mainly because of the very poor preservation of the planktonic foraminifers and the absence of some important zonal and stage markers, such as Globotruncana elevata, G. calcarata, and G. gansseri. However, the sedimentary record seems to be continuous from Santonian-Coniacian through the upper Maestrichtian.

The Cretaceous/Tertiary boundary is intact in Section $516 \mathrm{~F}-89-5$, at a sub-bottom depth of about $964 \mathrm{~m}$. The top of the Uppermost Cretaceous A. mayaroensis Zone is assigned to Sample 516F-89-5, 29.3-31.2 cm, whereas rare specimens of Globigerina eugubina date Sample 516F-89-5, 28-29.3 cm, as lowermost Paleocene. The relative abundance of planktonic foraminifers indicates that no major hiatus is present at the Cretaceous/Tertiary boundary at Hole 516F.

The upper Cretaceous sequence of Site 516 contains three remarkable intervals of conspicuous red coloration. The first, between Sections 516F-108-2 and 516F104-1, is possibly middle to late Campanian and is characterized by a distinct decrease of planktonic foraminifers. The others, between Sections 516F-96-2 and 516F94-2 and between Sections 516F-92-2 and 516F-91-2, are dated as middle to late Maestrichtian and show no change in the distribution and abundance of planktonic foraminiferal species.

Site 516 can be correlated with São Paulo Plateau Site 356 and Rio Grande Rise Sites 357 and 21. Exact correlation is difficult because of the absence of some of the generally accepted zonal markers.

\section{ACKNOWLEDGMENTS}

I am greatly indebted to Dr. R. Mark Leckie (Boulder) and Dr. Chr. Hemleben (Tübingen), who critically read the manuscript and made a number of valuable suggestions; to Dr. Pavel Cepek and Mr. Wilhelm Koch, who helped me with stratigraphic and taxonomic problems. For technical assistance in typing and drafting, I wish to thank Mrs. Freyer, Mrs. Werdin, and Mrs. Engel. I am grateful to the Deep Sea Drilling Project for the opportunity of collaborating and to the Deutsche Forschungsgemeinschaft for financial support.

\section{REFERENCES}

Pessagno, E. A., Jr., 1967. Upper Cretaceous planktonic foraminifera from the western Gulf Coastal Plain. Paleontogr. Americana, 5(37):245-445.

Petters, S. W., 1977. Upper Cretaceous planktonic foraminifera from the subsurface of the Atlantic Coastal Plain of New Jersey. $J$. Foraminiferal Res., 7(3):165-187.

Premoli Silva, I., and Boersma, A., 1977. Cretaceous planktonic foraminifers-DSDP Leg 39 (South Atlantic). In Supko, P. R., PerchNielsen, K., et al., Init. Repts. DSDP, 39: Washington (U.S. Govt. Printing Office), 615-641.

van Hinte, J., 1976. A Cretaceous time scale. Am. Assoc. Pet. Geol. Bull., 60(4):498-516.

Wonders, A. A. H., 1980. Middle and Late Cretaceous planktonic foraminifera of the western Mediterranean area. Utrecht Micropaleontol. Bull., 24.

Date of Initial Receipt: April 20, 1982 